\title{
Relationships among wood anatomy, hydraulic conductivity, density and shear parallel to the grain in the wood of 24-year-old Handroanthus vellosoi (Bignoniaceae)
}

\author{
Eduardo Luiz Longui ${ }^{1,4}$, Ivanka Rosada de Oliveira ${ }^{1}$, Ryan Combs Graebner ${ }^{2}$, Miguel Luiz Menezes Freitas ${ }^{1}$, \\ Sandra Monteiro Borges Florsheim ${ }^{1} \&$ José Nivaldo Garcia $^{3}$
}

\begin{abstract}
We studied the relationships among wood anatomy, hydraulic conductivity, density and shear parallel to the grain in the stem of Handroanthus vellosoi trees with the goal to identify possible trade-offs between hydraulic conductivity and mechanical properties. For this study we felled 12 trees with 24 -year-old and cut 10 -cm-thick disks at three heights: base of the trunk, one meter in height, and two meters in height. We propose that the relationship between hydraulic conductivity and mechanical resistance found along the $H$. velloso $i$ trunk indicates greater mechanical investment in the wood at the base of the trunk compared with the other two heights ( 1 and 2 meters). Anatomically, this would be represented by smaller diameter vessels and fibers with thicker walls. Consequently, strength investment implies lower water conductivity at the stem base. However, more studies are needed to determine whether this lower value with respect to 1 and 2 meters represents a significant effect on water transport along the stem.
\end{abstract}

Key words: axial variation, biomechanics, brazilian wood, ipê amarelo, trade-offs.

\section{Resumo}

Foram estudadas as relações entre anatomia da madeira, condutividade hidráulica, densidade aparente e cisalhamento paralelo à grã no tronco de árvores de Handroanthus vellosoi objetivando-se identificar os possíveis trade-offs entre a condutividade hidráulica e propriedades mecânicas. Para este estudo foram cortadas 12 árvores com 24 anos de idade, discos com $10 \mathrm{~cm}$ de espessura foram retirados em três alturas: base do tronco, um e dois metros de altura. Propomos que a relação entre a condutividade hidráulica e resistência mecânica encontrados ao longo do tronco H. vellosoi parece indicar um maior investimento mecânico na base do tronco em comparação com as outras duas alturas ( 1 e 2 metros), anatomicamente representada por vasos de menor diâmetro e fibras com paredes mais espessas. Consequentemente, um investimento em maior resistência mecânica implica em menor condutividade de água, contudo, mais estudos são necessários para determinar se este valor mais baixo em relação ao 1 e 2 metros representa um efeito significativo no transporte de água ao longo do tronco.

Palavras-chave: variação axial, biomêcanica, madeira brasileira, ipê amarelo, trade-offs.

\section{Introduction}

Handroanthus vellosoi (Toledo) Mattos is a native and endemic species of Brazil, with a geographical distribution in the Midwest (Goiás, Mato Grosso do Sul), Southeast (Minas Gerais, Rio de Janeiro, São Paulo) and South (Paraná) of country (BFG 2015). Popularly known as "ipê amarelo", the wood has a high density ( 0.80 to
$1.00 \mathrm{~kg} \cdot \mathrm{m}^{-3}$ ), with light sapwood and slightly pink heartwood, and high durability when exposed to weather. There are numerous uses for products of H. vellosoi. The wood is excellent for construction, and can be used in paper production, or as biomass for energy. The bark can be used medicinally, for landscaping of parks and forestry roads, and for reforestation (Carvalho 2003).

\footnotetext{
${ }^{1}$ Instituto Florestal, Divisão de Dasonomia, R. do Horto 931, 02377-000, São Paulo, SP, Brazil.

${ }^{2}$ Oregon State University, 1500 SW Jefferson St. Corvallis, OR 97331, Corvallis, Oregon, United States of America.

${ }^{3}$ Universidade de São Paulo, Depto. Ciências Florestais, Av. Pádua Dias 11, 13418-900, Piracicaba, SP, Brazil.

${ }^{4}$ Author for correspondence: edulongui@gmail.com
} 
Studies of trade-offs between hydraulic conductivity and mechanical strength of wood are rare despite the possible ecological and economic importance (Woodrum et al. 2003). In ecological terms, these studies help us understand more broadly the relation between the transport of water and wood resistance in different species, while economically may indicate the planting of more suitable species to certain environments. Most of the existing studies have focused on plants in the northern hemisphere, which in many cases have different anatomical constitutions (arrangement of their pores or vessels into growth rings) than those found in tropical forests. The trees in north hemisphere exhibit ring porous and semi ring porous, whereas most tropical trees have diffuse porous. These anatomical variations could have an important influence on the relationship between hydraulic conductivity and mechanical strength of wood.

Recent studies have shown an axial widening of the vessel elements from the stem apex to base of trees (Anfodillo et al. 2006; Olson \& Rosell 2013). Change in vessels diameter in xylem architecture is crucial for trees growth to maintain the hydraulic efficiency (Petit \& Anfodillo 2009) and protect the vessel from embolism. Larger vessel diameter is said to be more efficient in water conductivity than smaller vessel diameter (Fan et al. 2012).

Examples of studies between hydraulic conductivity and mechanical strength include Gartner (1991a, b), which studied Toxicodendron diversilobum (Torr. \& A. Gray) Greene, a plant that grows as a vine when support is present and as a shrub when support is absent. Wagner et al. (1998) studied four co-occurring species of chaparral shrubs in different locations of Santa Monica, California: Adenostoma sparsifolium Torr., A. fasciculatum Hook. \& Arn., Ceanothus megacarpus Nutt. and $C$. spinosus Nutt. Woodrum et al. (2003) studied five Acer species in Michigan State: Acer negundo L., A. saccharinum L., A. rubrum L., A. nigrum Michx. f. and $A$. saccharum Marshall. However, interactions between wood anatomy, hydraulic conductivity, and mechanical strength are complex, which may in part explain the deficiency of studies on this topic (Woodrum et al. 2003).

Fournier et al. (2006) studied how the combination of morphological, anatomical, and physiological characteristics may establish the height growth strategy to balance biomechanical functional traits. Combinations of size, shape and material properties influence the risk of trunks and branches bending or breaking, and are crucial to the survival of trees. A more rigid wood is generally constituted of a greater proportion of fibers with thick walls, but the cost of construction of this tissue is high. In contrast, wood with larger vessels is hydraulically more efficient, but has lower density and therefore will have lower rigidity. Thus, the hydraulic and mechanical constraints can be seen as associated functions and physiological compromises have to be satisfied by adaptations and modifications of the plant (Rowe \& Speck 2004).

Lachenbruch \& McCulloh (2014) presented a review to assess how cells, tissues, organs, and whole plants perform both hydraulic and mechanical functions, and tried to explain how the morphological alterations that affect this dual functionality are varied. Key strategies that plants can use to balance hydraulic mechanical requirements are plasticity in cell morphology, alignment and function, and in the allocation and geometric distribution of different tissues.

We proposal to increase the knowledge about the relationship between hydraulic and mechanical requirements in trees, with a focus on the trade-offs between hydraulic conductivity and mechanical strength in tree trunk of Handroanthus vellosoi, a native species from Brazil.

\section{Materials and Methods}

Location and sampling

All samples came from a Handroanthus vellosoi Plantation Forest in the Luiz Antônio Experimental Station (LAES) in Luiz Antônio City, São Paulo state Brazil (2140'S, 4749’W, elevation $550 \mathrm{~m}$ ). Climate is Cwa (humid subtropical climate) in the Köppen system. Figure 1 shows the climate characterization of Luiz Antônio (CEPAGRI 2016).

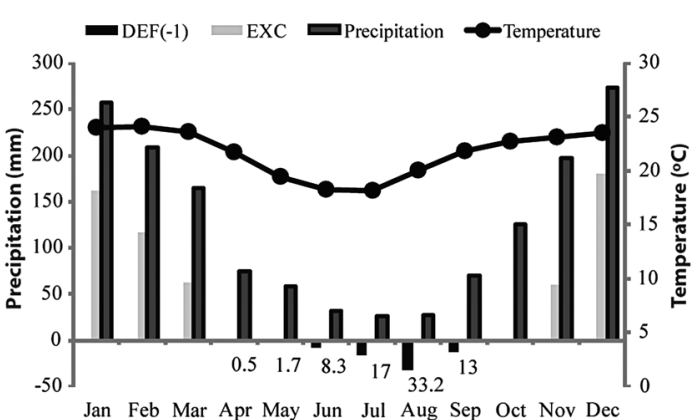

Figure 1 - Average monthly sum of precipitation, hydric deficit (def-1), hydric excedent (exc), and mean temperature (lines) at the Luiz Antonio city - 1961-1990 (CEPAGRI 2016). 
The plantation was established with six randomized blocks at $3 \mathrm{~m} \times 2 \mathrm{~m}$ spacing, and trees were 24 years old at time of harvest. From each block, we randomly harvested 12 trees. Trees averaged $12.7 \mathrm{~m}$ in height (range of 9.7-14.7 m), and disks averaged $17.7 \mathrm{~cm}$ at the base (range of 9.5-23 cm), $13.9 \mathrm{~cm}$ at $1 \mathrm{~m}$ height (range of $8.5-19 \mathrm{~cm}$ ), and $12.9 \mathrm{~cm}$ at $2 \mathrm{~m}$ height (range of $7.5-17.5 \mathrm{~cm})$.

From each 12 harvested tree in October 2010, we took a 10-cm-thick disk at the base of the trunk, at $1 \mathrm{~m}$, and at $2 \mathrm{~m}$, for a total of 36 disks. This methodology was adopted because the stems of most trees bifurcated at about $2 \mathrm{~m}$. From each disk, we then took two samples $\left(3 \times 2 \times 1.5 \mathrm{~cm}^{3}\right.$, axial $\times$ tangential $\times$ radial) from opposite sides of the disk and adjacent to the bark (Fig. 2). All analyses were performed on each sample in the following order: density, shear parallel to the grain, and a series of anatomical analyses.

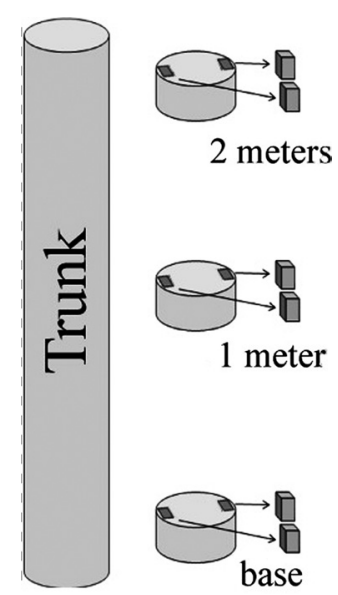

Figure 2 - Illustration of sampling design showing the location of the two replicated samples at each height.

\section{Density}

Density $\left(r_{12}\right)$ was determined at equilibrium moisture content (EMC-12\%) condition and calculated by the relation between mass and volume at the same moisture content. Volume was evaluated by the volume of water displaced during immersion of the specimens $(3 \times 2 \times 2 \mathrm{~cm})$ (Glass \& Zelinka 2010), as $r_{12}=M / V$,

Where $r_{12}=$ density $\left(\mathrm{kg} \cdot \mathrm{m}^{-3}\right) ; M=$ wood mass at $12 \%$ moisture content $(\mathrm{kg})$; and $V=$ wood volume at $12 \%$ moisture content $\left(\mathrm{m}^{3}\right)$.
Shear parallel to the grain

Samples $2 \times 2 \times 3 \mathrm{~cm}$ with $5 \mathrm{~cm}^{2}$ shear area, were tested. At one end was a characteristic cut of the shear samples (ASTM 2005-2006). The samples had previously been measured with a caliper to determine the areas of each sample (12\% moisture). The load application velocity was 2.5 $\mathrm{MPa}\left(\mathrm{N} \mathrm{min}{ }^{-1}\right)$.

\section{Anatomical analyses}

A block $\left(2 \mathrm{~cm}^{3}\right)$ from each sample was then softened in a solution of boiling water and glycerin (4:1) for one hour. Twenty-micron thick transverse and longitudinal sections were then made on a sliding microtome. The sections were bleached with $60 \%$ sodium hypochlorite and washed in water (Johansen 1940). Some of the remaining sample was used for macerations, following the Franklin method (Berlyn \& Miksche 1976). The thin sections and the macerated material were then stained with safranin (1\%, in Ethanol) and mounted in a water and glycerin solution (1:1) on slides.

Anatomical measurements were then made using image analysis software (Image Pro 6.3) on a computer attached to an Olympus CX 31 compound microscope equipped with an Olympus Evolt E330 camera. The terminology and characterization of wood followed the IAWA list (IAWA Committee 1989). Transverse sections were used to measure vessel diameters and vessel frequency, and fiber wall thicknesses. For these measurements, we took five photos for each transverse wood section (one for each of the two samples for a given disk), and from each photo we made at least 25 measurements.

Microfibril angle was estimated from the longitudinal sections using an Olympus CX 31 compound microscope with polarization and a rotating base. Slides were placed on the rotating base and fibers vertically aligned, the wall being watched in the field of fibers, then the base was rotated until the fiber wall presenting a darker coloration, called maximum extinction position at this time is noted angle (Donaldson 2008).

\section{Hydraulic conductivity}

Hydraulic conductivity was calculated based on vessel diameter, using the following equation: $\mathrm{Kh}=\pi \mathrm{D} 4 / 128 \eta$, where $\mathrm{D}$ is the diameter, $\eta$ is the viscosity index of water $(1.002 \times 10-9 \mathrm{MPa} s$ at $20^{\circ} \mathrm{C}$ ), and $\mathrm{Kh}$ is the hydraulic conductivity (Scholz et al. 2013). 
Statistical analysis

Initially, the values from the two samples per disk were pooled, so there was one value per disk. To evaluate the effect of height within tree on the variables (vessel diameter, vessel frequency, fiber wall thickness, microfibril angle, hydraulic conductivity, density, and shear parallel to the grain) we used analysis of variance (ANOVA). Data were square root-transformed, to achieve a normal distribution. When a significant difference was observed between heights, we used the Tukey test to identify the determinant pair of differences. To examine the relationships among variables, we use the samples separately for Pearson correlation, and when we observe the presence of outliers, they were removed from the analysis and graphing. This explains why the number of samples in scatterplots range from 69 to 72 ( 72 samples were present in all datasets before outliers were removed). Results with $\mathrm{P}<0.05$ were considered significant.

\section{Results}

Density and shear parallel to the grain were significantly higher at the base $\left(925 \mathrm{~kg} \mathrm{~m}^{-3}\right.$ and 14.2 $\mathrm{MPa}$, respectively) and at $1 \mathrm{~m}\left(897 \mathrm{~kg} \mathrm{~m}^{-3}\right.$ and $14.6 \mathrm{MPa})$ than at $2 \mathrm{~m}\left(836 \mathrm{~kg} \mathrm{~m}^{-3}\right.$ and 12.3 MPa) (Fig. 3a,b). Fiber wall thickness was higher at the base $(7.1 \mu \mathrm{m})$ than at the upper positions (1 $\mathrm{m}=6.6$ and $2 \mathrm{~m}=6.7$ ) (Fig. 3c). Vessel diameter was lowest at the base $(91 \mu \mathrm{m})$, and increased significantly at $1 \mathrm{~m}(100 \mu \mathrm{m})$ and again at $2 \mathrm{~m}(106$ $\mu \mathrm{m})$ (Figs. 3d; 4a-c). Vessel frequency was higher at $2 \mathrm{~m}\left(14\right.$ cells $\left.\mathrm{mm}^{-2}\right)$ than at $1 \mathrm{~m}\left(12\right.$ cells $\left.\mathrm{mm}^{-2}\right)$, but neither of these heights differed significantly from the value at the base $\left(13\right.$ cells $\mathrm{mm}^{-2}$ ) (Figs. $3 \mathrm{e} ; 4 \mathrm{a}-\mathrm{c})$. Hydraulic conductivity was lowest at the base $\left(2.11 \mathrm{M}^{4} \cdot \mathrm{MPa} \cdot \mathrm{s}^{-1} \cdot \mathrm{m}^{-1}\right)$, and increased significantly at $1 \mathrm{~m}\left(3.08 \mathrm{M}^{4} \cdot \mathrm{MPa} \cdot \mathrm{s}^{-1} \cdot \mathrm{m}^{-1}\right)$ and at $2 \mathrm{~m}\left(3.71 \mathrm{M}^{4} \cdot \mathrm{MPa} \cdot \mathrm{s}^{-1} \cdot \mathrm{m}^{-1}\right)$ (Fig. 3f). Microfibril angle showed no significant difference among three axial positions.

We observed positive correlation between density and shear parallel to the grain (Fig. 5a). There were negative correlations between fiber wall thickness and microfibril angle (Fig. 5b); density and hydraulic conductivity (Fig. 5c); shear parallel to the grain and hydraulic conductivity (Fig. 5d); density and vessel diameter (Fig. 5e); and density and vessel frequency (Fig. 5f).

\section{Discussion}

We noticed a trade-off between hydraulic efficiency and mechanical strength in the
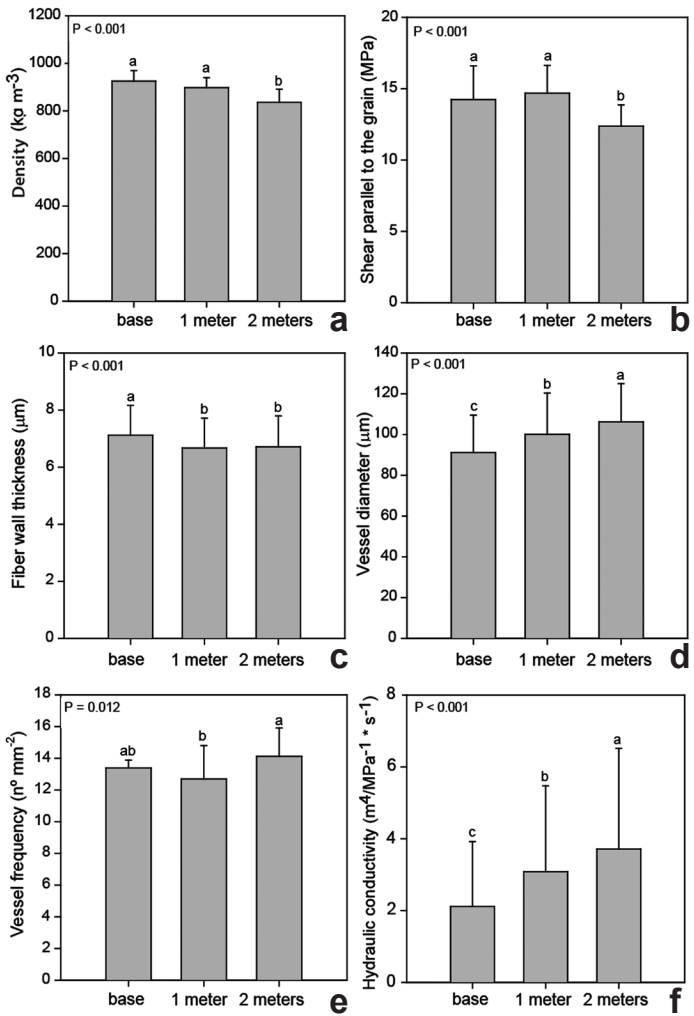

Figure 3 - Axial variation in Handroanthus vellosoi wood - a. density; b. shear parallel to the grain; c. fiber wall thickness; d. vessel diameter; e. vessel frequency; f. hydraulic conductivity. The columns represent the average of 72 samples. Different letters indicate significant differences $(\mathrm{P}<0.05)$.

Handroanthus vellosoi stem. Wood from stem base showed higher density and shear, and lower hydraulic conductivity that are directly related to smaller diameter vessels. According to Saranpää (2003) and Kretschmann (2010), larger vessel diameters are more efficient in water conduction than those with smaller diameter (Fan et al. 2012).

Similar to results presented in this study, we have observed narrower vessels at the stem base compared to the root and others stem positions in five Brazilian native species (unpublished data), including Handroanthus ochraceus (Cham.) Mattos, a species of the same genus of this study, which seems to indicate adaptations related to both concurrent functions: water transport and mechanical strength.

Domec \& Gartner (2002) studied trade-offs between hydraulic and mechanical properties of Douglas-fir wood conclude that large radial variation in the wood anatomy of trees is an 

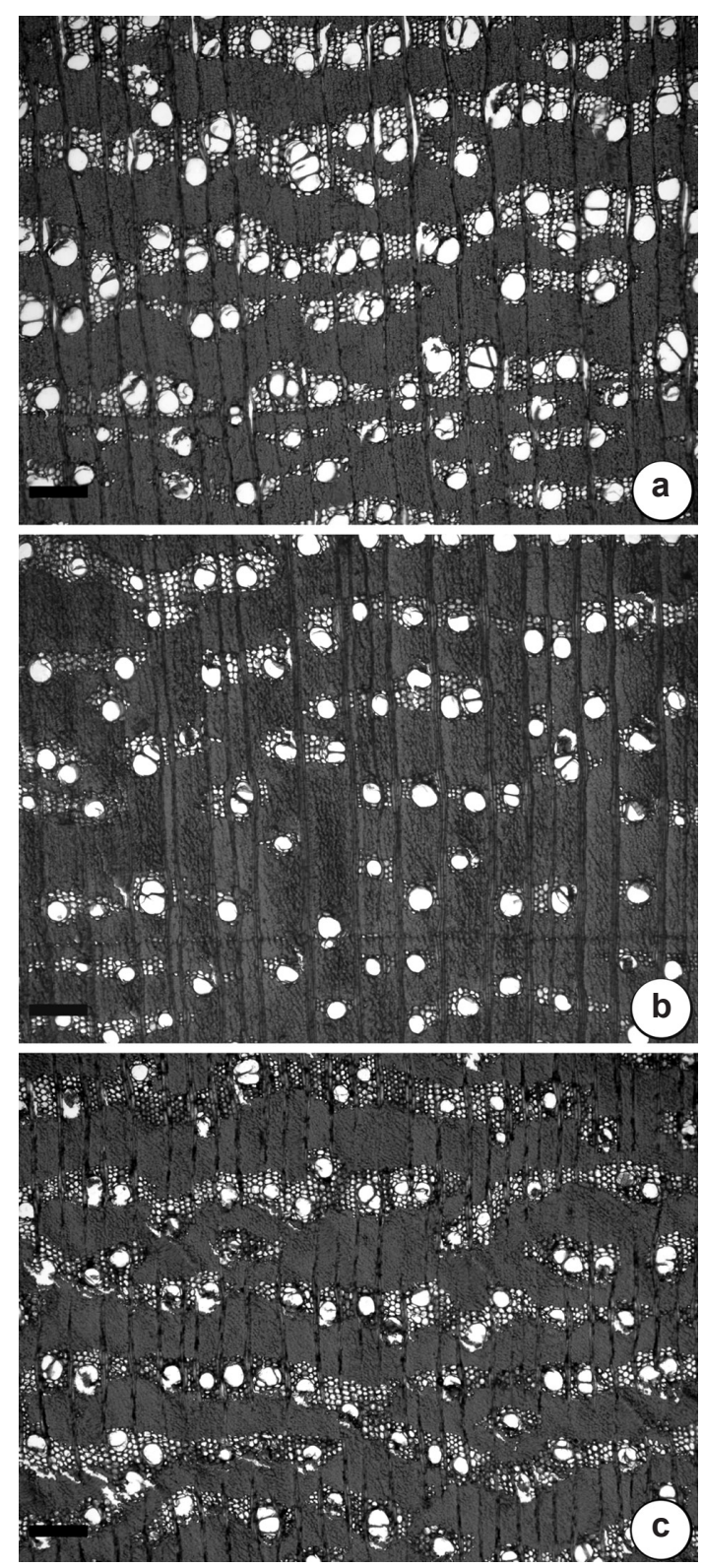

Figure 4 - Transverse sections of Handroanthus vellosoi wood - a. 2 meters high; b. 1 meter high; c. stem base. Scale bars $=500 \mu \mathrm{m}$.

adaptation to hydraulic rather than mechanical requirements. However, hydraulic conductivity and mechanical requirements are evolutionarily related (Rowe \& Speck 2005). The hydraulic conductivity appears to be slightly ahead to guide the evolution and consequently it may happen during ontogeny.

Studies have been found a sharp drop in vessel diameter just above the branch junctions, which the authors call "hydraulic bottlenecks" (Tyree
\& Zimmermann 2002). However, the effect of all junction constrictions in a tree is unlikely to have much impact on the water conductivity (Tyree \& Alexander 1993; Tyree \& Zimmermann 2002). The point is: if this vessel narrowing at stem base of $H$. vellosoi has no impact on the conductivity, why does it occur?

We suggest that narrower vessels at stem base may be a pattern found in several trees, and then could these bottlenecks contribute in water transport by pressure differences along vessels or smaller diameter vessels of stem base are related to mechanical requirements, since trees, as tallest self-supporting plants, need resist to static loads, lateral wind forces, or by its own self-weight, with a perfectly stiff anchorage (Niklas 1992; Moulia \& Fournier-Djimbi 1997). Then, decreasing in vessel diameter tends to make denser and stronger wood, since vessel lumens represent weak areas of the xylem (Wagner et al. 1998; Baas et al. 2004).

Relationship between anatomy and mechanical support is more clearly evidenced in the vines (nonself-supporting plants) compared with trees (selfsupporting plants), as the relationships between wood mechanical properties and vessel diameter reported by Ewers \& Fisher (1991), Gartner (1991a, b) and Chiu \& Ewers (1992), but also is displayed in shrubs (Wagner et al. 1998), self-supporting plants.

Associated with smaller vessel diameter at stem base, we also noticed thicker wall fibers, which according to Rowe \& Speck (2004) is related to more resistant wood. Woodrum et al. (2003) studied hydraulic, biomechanical, and anatomical interactions of xylem from five species of Acer and reported relationships between fiber features and mechanical properties.

We emphasize the high construction cost of a tissue with thicker wall cells, because it involves greater carbon incorporation and this is common in long-lived climax species (Larjavaara \& MullerLandau 2010), such as H. vellosoi. Applying this knowledge to individual variation, it is concluded that there must be the higher construction cost at stem base, and this should play a key role in sustaining this trees, because as a climax species, the plant must invest in the high construction cost, which will provide long-term benefits (Larjavaara \& Muller-Landau 2010), in this case adequate mechanical support.

The negative correlation between density with vessel diameter and vessel frequency also show the role of these anatomical features in density and consequently in strength. According to Kollmann 

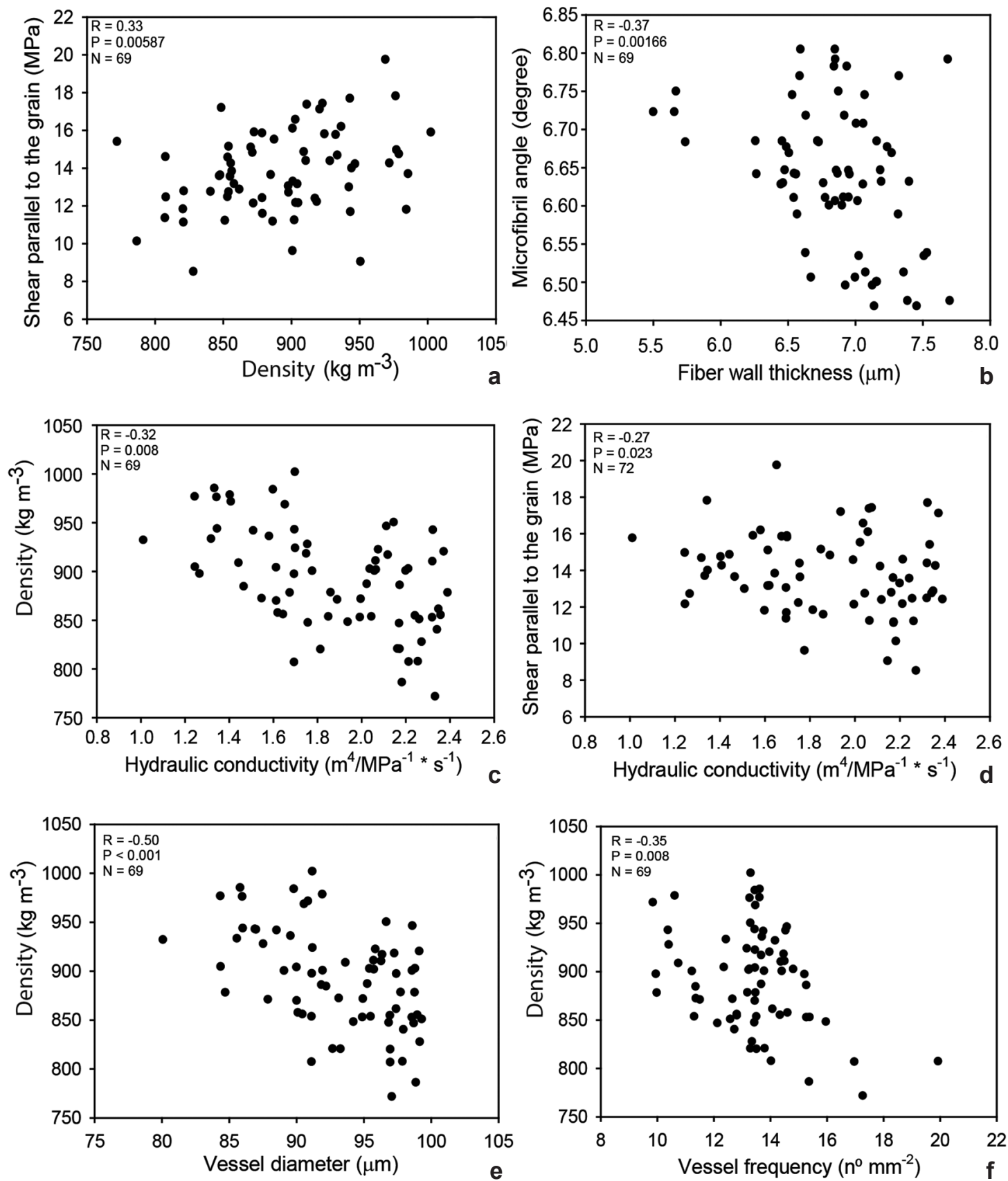

Figure 5 - Scatterplots between - a. shear parallel to the grain and density; b. microfibril angle and fiber wall thickness; c. density and hydraulic conductivity; d. shear parallel to the grain and Hydraulic conductivity; e. density and vessel diameter; f. density and vessel frequency.

\& Côte (1968), among the physical properties, density is considered one of the main parameters for assessing wood quality, since this property is an indicator of other physical and mechanical properties.
Microfibril angle is also indicative for the wood strength (Butterfield 2003). Both conifers and hardwoods, microfibril angles is larger at the base of the tree for a given ring number from the pith, and decreases with height, increasing slightly 
at the top tree, but in hardwoods this variation is smaller and much smaller microfibril angles in juvenile wood (Donaldson 2008). Large microfibrils angles are related with low stiffness, i.e. greater flexibility and this condition is important to the stem, particularly the younger to resist wind.

We did not notice axial variation in microfibril angle in the $H$. vellosoi stem, despite the positive correlation between microfibril angle and fiber wall thickness. But, according to Donaldson (2008) this relationship is coincidental since microfibril angle is not related to tracheid wall thickness, and this relationship is due to amount variation between juvenile wood and latewood. Possibly this relationship is due radial variation of these properties from juvenile wood to mature wood (Hein et al. 2013).

\section{Conclusion}

We propose that the relationship between hydraulic conductivity and mechanical resistance found along the Handroanthus vellosoi trunk indicates greater investment in the mechanical properties of wood at the trunk base, relative with the other two heights ( 1 and 2 meters). This was anatomically represented by smaller diameter vessels and fibers with thicker walls. Consequently, strength investment implies lower water conductivity at the stem base, but more studies are needed to determine whether this lower value with respect to 1 and 2 meters represents a significant effect on water transport along the stem.

\section{Acknowledgments}

The authors thank Conselho Nacional de Desenvolvimento Científico e Tecnológico - CNPq "National Counsel of Technological and Scientific Development" for a grant to Ivanka Rosada de Oliveira (113229/2011-9). We also thank Sonia Godoy Campião and Diego Romeiro for laboratory assistance and Israel Luiz de Lima for field work. We are especially grateful to Barbara Lachenbruch for helpful comments. Authors are also thankful for the reviewers for their critical suggestions on the previous version of the manuscript.

\section{References}

Anfodillo T, Carraro V, Carrer M, Fior C \& Ross S (2006) Convergent tapering of xylem conduits in different woody species. New Phytologist 169: 279-290.

ASTM - American Society for Testing Materials (20052006) Annual Book of ASTM Standards. Wood, Standard. Vol. 4.10. ASTM, Easton. Pp. 143-183.
Baas P, Ewers FW, Davis SD \& Wheeler EA (2004) Evolution of xylem physiology. In: Poole I \& Hemsley A (eds.) Evolution of plant physiology. Linnean Society Symposium Series. Vol. 1. Elsevier Academic Press, London. Pp. 273-295.

Berlyn GP \& Miksche JP(1976) Botanical microtechnique and cytochemistry. The Iowa University Press, Iowa. 326p.

BFG - The Brazil Flora Group (2015) Growing knowledge: an overview of seed plant diversity in Brazil. Rodriguésia 66: 1085-1113.

Butterfield BG (2003) Wood anatomy in relation to wood quality. In: Barnett JR \& Jeronimidis G (eds.) Wood quality and its biological basis. Blackwell Publishing Ltd., Oxford. Pp. 30-52.

Carvalho PER (2003) Espécies arbóreas brasileiras. Vol. 1. Embrapa Informação Tecnológica, Brasília. 1039p.

Centro de Pesquisas Meteorológicas e Climáticas Aplicadas à Agricultura - CEPAGRI. Clima dos municípios paulistas. Available at $<$ http://www. cpa.unicamp.br/outras informacoes/clima-dosmunicipios-paulistas. html>. Access on April 2016.

Chiu ST \& Ewers FW (1992) Xylem structure and water transport in a twiner, a scrambler, and a shrub of Lonicera (Caprifoliaceae). Trees: Structure and Function 6: 216-224.

Domec JC \& Gartner BL (2002) Age-and position-related changes in hydraulic versus mechanical dysfunction of xylem: inferring the designs criteria for Douglasfir wood structure. Tree Physiology 22: 91-104.

Donaldson LL (2008) Microfibril angle: measurement, variation and relationships - a review. IAWA Journal 29: 345-386.

Ewers FW \& Fisher JB (1991) Why vines have narrow stems: histological trends in Bauhinia. Oecologia 88: 233-237.

Fan ZX, Zhang SB, Hao GY, Slik JWF \& Cao KF (2012) Hydraulic conductivity traits predict growth rates and adult stature of 40 Asian tropical tree species better than wood density. Journal of Ecology 100: 732-741.

Fournier M, Stokes A, Coutand C, Fourcaud T \& Moulia B (2006) Tree biomechanics and growth strategies in the context of forest functional ecology. In: Herrel A, Speck T \& Rowe N (eds.) Ecology and biomechanics: a mechanical approach to the ecology of animals and plants. CRC Press, Boca Raton. Pp. 1-34.

Gartner BL (1991a) Stem hydraulic properties of vines vs. shrubs of western poison oak, Toxicodendron diversilobum. Oecologia 87: 180-189.

Gartner BL (1991b) Structural stability and architecture of vines vs. shrubs of poison oak, Toxicodendron diversilobum. Ecology 72: 2005-2015.

Glass S \& Zelinka SL (2010) Moisture relations and physical properties of wood. In: Ross R (ed.) Wood handbook, Centennial edition. FPL-GTR-190. U.S. Department of Agriculture, Forest Service, Forest Products Laboratory, Madison. 508p. 
Hein PRG, Silva JRM \& Brancheriau L (2013) Correlations among microfibril angle, density, modulus of elasticity, modulus of rupture and shrinkage in 6-year-old Eucalyptus urophylla $\mathrm{x}$ E. grandis. Maderas Ciencia y tecnologia 15: 171-182.

IAWA Committee (1989) IAWA list of microscopic features for hardwood identification. IAWA Bulletin 10: 219-332.

Johansen DA (1940) Plant microtechnique. Mac GrawHill, New York. 533p.

Kollmann FFP \& Cotê WA (1968) Principles of wood science and technology. Vol. 1. Springer-Verlag, Berlim. 592p.

Kretschmann DE (2010) Mechanical properties of wood. In: Ross R (ed.) Wood handbook. $100^{\text {th }}$ ed. U.S. Department of Agriculture, Forest Service, Forest Products Laboratory. General Technical Report FPL-GTR-190, Madison. 508p.

Lachenbruch B \& McCulloh K (2014) Traits, properties, and performance: how woody plants combine hydraulic and mechanical functions in a cell, tissue, or whole plant. New Phytologist 204: 747-764.

Larjavaara M \& Muller-Landau HC (2010) Rethinking the value of high wood density. Functional Ecology 24: 701-705.

Lorenzi H (2002) Árvores brasileiras: manual de identificação e cultivo de plantas arbóreas do Brasil. $2^{\underline{a}}$ ed. Vol. 1. Instituto Plantarum, Nova Odessa. 368p.

Moulia B \& Fournier-Djimbi M (1997) Optimal mechanical design of plant stems: The models behind the allometric power laws. In: Jeronimidis G \& Vincent JFV (eds.) Plant biomechanics, 43-55. Centre for Biomimetics, University of Reading, Reading. 379p.

Niklas K (1992) Plant biomechanics: an engineering approach to plant form and function. University of Chicago Press, Chicago. 622p.
Olson ME \& Rosell JA (2013) Vessel diameter-stem diameter scaling across woody angiosperms and the ecological causes of xylem vessel diameter variation. New Phytologist 197: 1204-1213.

Petit G \& Anfodillo T (2009) Plant physiology in theory and practice: an analysis of the WBE model for vascular plants. Journal of Theoretical Biology 259: 1-4.

Rowe NP \& Speck T (2004) Hydraulics and mechanics of plants: novelty, innovation, and evolution. In: Poole I \& Hemsley A (eds.) Evolution of plant physiology. Linnaean Society Symposium Series. Elsevier Academic Press, London. Pp. 297-325.

Rowe NP \& Speck T (2005) Plant growth forms: an ecological and evolutionary perspective. New Phytologist 166: 61-72.

Saranpää P (2003) Tree growth and wood quality. In: Barnett JR \& Jeronimidis G (eds.) Wood quality and its biological basis. Blackwell Publishing Ltd., Oxford. Pp. 87-117.

Scholz A, Klepsch M, Karimi Z \& Jansen S (2013) How to quantify conduits in wood? Frontiers in Plant Science 4: 1-11.

Tyree MT \& Alexander JD (1993) Hydraulic conductivity of branch junctions in three temperate tree species. Trees: Structure and Function 7: 156-159.

Tyree MT \& Zimmermann MH (2002) Xylem structure and the ascent of sap. Springer Verlag, Berlin. 283p.

Wagner KR, Ewers FW \& Davis SD (1998) Tradeoffs between hydraulic efficiency and mechanical strength in the stems of four co-occurring species of chaparral shrubs. Oecologia 117: 53-62.

Woodrum CL, Ewers FW \& Telewski FW (2003) Hydraulic, biomechanical, and anatomical interactions of xylem from five species of Acer (Aceraceae). American Journal of Botany 90: 693-699. 